\title{
TUBERCULOSIS IN RENAL TRANSPLANT PATIENTS
}

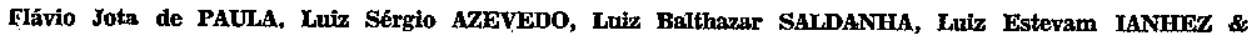 \\ Emil SABBAGA
}

\section{S U M M A R $\mathbf{Y}$}

Tuberculosis (TB) was diagnosed in 25 of 466 patients who underwent renal transplant over a period of 15 years. TB developed from 1 month to 9 years post-transplant. In $56 \%$ of the cases the onset was within the first post-transplant year. TB affected several isolated or combined organs. Pulmonary involvement was present in $76 \%$ of cases, either as isolated pleuro-pulmonary $(56 \%)$ or associated with other sites $(20 \%)$. The non-pulmonary sites were: skin, joints, tests, urinary tract, central nervous system and lymphonodules. The diagnosis was confirmed by biopsy in $64 \%$ of the cases, by identification of tubercle ba cilli in $24 \%$ and only at necropsy in $12 \%$, Biopsy specimens could be classified in three histological forms: exudative, that occurred in early onset and more severe cases granulomatous in late onset and benign cases; and mixed in intermediate cases. Azathioprine dosages were similar along post-transplant time periods in TB patients and in the control groups; and in TB patients who were cured and who died. The number of steroid treated rejection crises was greater in TB than in the control group. Prednisone doses were higher and the num. ber of rejection crises was greater in TB patients who died than in those who were cured. Fifteen patients were cured and ten died, two of them of causes unrelated to TB. Six of the eight TB-related deaths occurred in the first 6 post-transplant months. The outcome was poor in patients in whom TB arose early in post-transplant period and where the exudative or mixed forms were present; whereas the prognosis was good in patients with late onset and granulomatous form of TB. In one patient TB was transmitted by the allograft.

KEY WORDS: Tuberculosis; Kidney transplantation; Infection; Immunosuppression.

\section{INTRODUCTION}

Infection is a frequent complication and the main cause of death in renal transplant patients. This high frequency of infection has been associated with immunosuppressive the rapy ${ }^{20}$. Tuberculosis (TB) affecting these patients has been reported since as far back as $1964{ }^{28}$ either as isolated case reports or as small series 21,22 . Two reviews have been pu- blished 15,16. The real prevalence and the ade quate management and therapy are still dobatable.

\section{PATIENTS AND METHODS}

A retrospective analysis of 25 cases of TB diagnosed among 466 patients who underwent

Renal Transplant Unit, "Hospital das Clínicas" of University of São Paulo Medical School.

Address for correspondence: Dr. Flávio Jota de Paula. Unidade de Transplante Renal, Fospital das Clinicas da Facuidade de Medicina da Universidade de São Paulo. Av. Dr. Enéas de Carvalho Aguiar, 255. Caixa Postal 8091. CEP 05403 Săo Săo Paulo, SP - Brasil. 
PAULA, F. J. de; AZEVEDO, L. S.; SALDANHA, L. B.; IANHEZ, L. E. \& SABBAGA, E. - Tuberculosis in renal transplant patients, Rev. Inst. Med. trop. São Paulo, 29:268-275, 1987.

renal transplantation over a period of 15 years was carried out. This is an incidence of $5.6 \%$. The minimal follow-up period was 2 years. Immunosuppression consisted of Azathioprine $2 \mathrm{mg} / \mathrm{kg} /$ day and prednisone, initially in the dose of $1.5 \mathrm{mg} / \mathrm{kg} /$ day, decreasing thereafter progressively to reach 0 to $15 \mathrm{mg} /$ day. Any rejection crises 'were treated, until the 1974 by increasing the dosage of oral prednisone and thereafter by three to five courses of $1 \mathrm{~g}$ of intravenous methylprednisolone (table I). Six teen patients were male. Ages ranging from 14 to 60 years. The kidneys used were from living related donors in 20 patients and from cadaver donors in five.

T A B L E I

Immunosupression and post-transplant periods

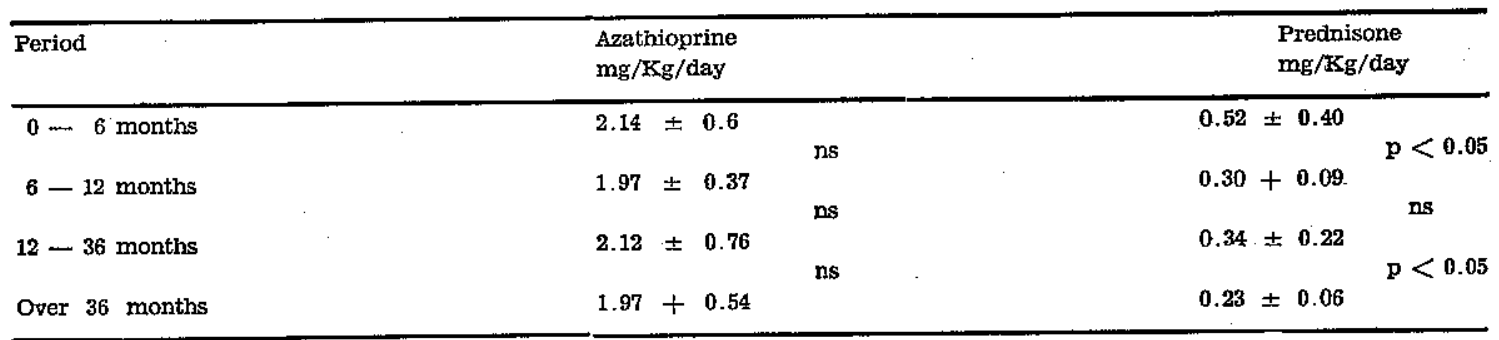

A control group consisted of 25 patients. For each patient with TB we selected another patient who had had no infectious complica tions, who had undergone transplantation at the same time, had received the kidney from the same type of donor (living-related/cadaver), was of the same sex and was of equiva. lent age. For this purpose the ages were divided into 10 year periods. The statistical analyses were based on Student's " $t$ " test and "chi-square" tests, with 5\% probability as the significance level.

\section{RESULTS}

The initial signs and symptoms are sum. marised in table II and the sites of involvement in figure 1. Pulmonary affection was present in 14 patients $(56 \%)$ either as isolated pulmonary (nine cases) or pleuropulmonary (five cases). In a further five cases it was associated with other sites of involvement. Thus, the total pulmonary involvement was $76 \%$ (19 patients). In six patients TB occurred in non-pulmonary sites only. Chest X-ray findings in patients with pulmonary involvement are summarised in table III.

TB developed from 1 month to 9 years post-transplantation. In nine patients (36\%) TB onset was within the first 6 months after the transplantation. A further four patients (20\%) developed TB during the following 6 months. Thus in 13 patients $(56 \%)$ the onset
T A B I E II

Signs and symptoms AT the onset of TB

\begin{tabular}{lrr}
\hline & N. & $\%$ \\
\hline Fever & 18 & 72 \\
Couch & 11 & 44 \\
Anorexia & 7 & 28 \\
Skin lesion & 3 & 12 \\
Asthenia & 2 & 8 \\
Jaundice & 2 & 8 \\
Myalgia & 2 & 8 \\
Resp. insufficiency & 2 & 8 \\
Weight Ioss & 2 & 8 \\
Orchitis & 2 & 8 \\
Arthralgia & 1 & 4 \\
Meningeal irritation & 1 & 4 \\
Urinary symptoms & 1 & 4 \\
\hline
\end{tabular}

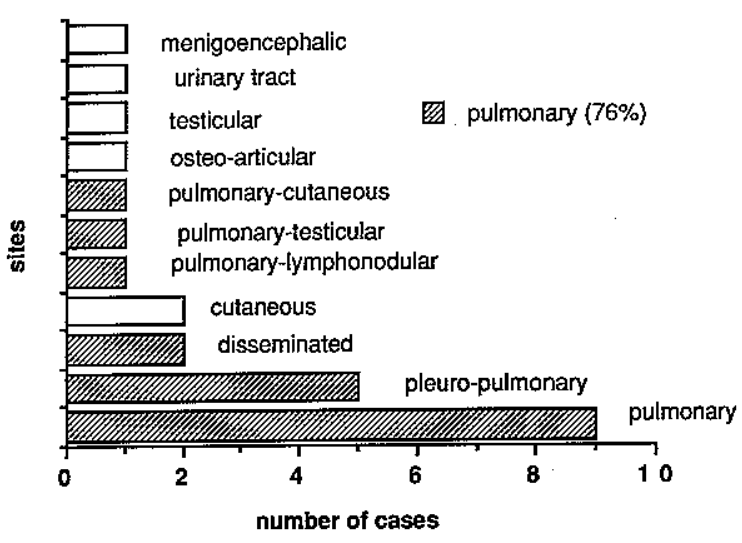

Fig. 1 - Sites of involvement.

of TB was in the first year. In these patients, pulmonary involvement was present in all but 
PAULA, F. J. de; AZEVEDO, L. S.; SALDANHA, L. B.; IANHEZ, L. E. \& SABBAGA, E. - Tuberculosis in renal transplant patients. Rev. Inst. Med. trop. São Paulo, 29:268-275, 1987.

TA B I E III

Chest $\mathrm{X}$-ray findings in cases of pulmonary involvement

\begin{tabular}{lcc}
\hline & N. & $\%$ \\
\hline Pulmonary infiltration only & 10 & 52.6 \\
Pulmonary infiltration and & & \\
pleuraI involvement & 5 & 26.3 \\
Pleural involvement only & 3 & 15.3 \\
$\begin{array}{c}\text { Pulimonary infiltration and } \\
\text { mediastinal enlargement }\end{array}$ & 1 & 5.26 \\
\hline
\end{tabular}

one. The other 12 cases were observed uniformiy from 1 to 9 years after the transplantation (figure 2). All but one case of nonpulmonary involvement occurred after the first post-transplant year. The two cases of miliary TB occurred during the first 6 months.

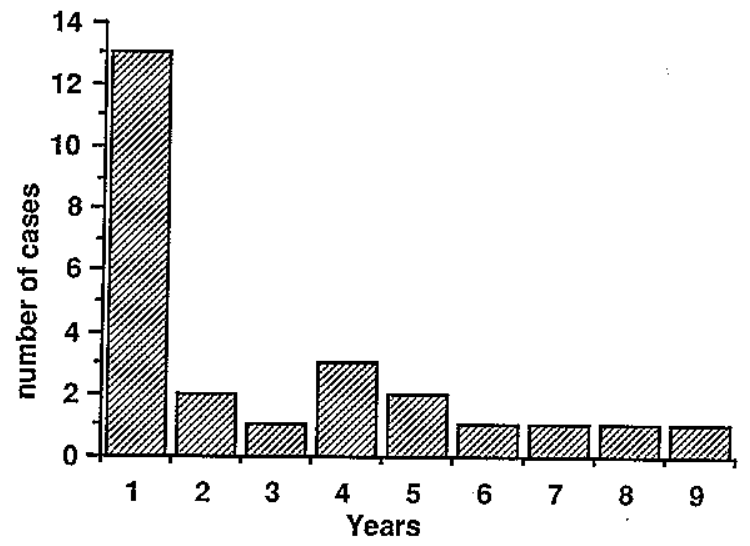

Fig. 2 - Onset of TB and post-transplant periods.

The diagnosis of TB was confirmed in 16 patients $(64 \%)$ by biopsy of the affected organ. In four patients who had multiple organ irvolvement, biopsies were performed at different sites. In six patients $(24 \%)$ the diagnosis was confirmed by the identification of the tubercle bacilli (by direct staining or by culture in specific media) in sputum, urine, pleural effusion and cerebral-spinal fluid. In three patients TB was diagnosed only at necropsy.

In 13 cases the biopsied specimens could be retrospectively reassessed. They could be classified in three forms: (a) exudative (three cases): polimorphonuclear neutrophil exudate, disrupture of the basic tissular pattern and ne crosis, highly similar to a common pyogenic infection. However, microbiological staining disclosed abundant acidfast bacilli bearing the features of tubercle bacilli; (b) gxanulomatous (seven cases): the typical tuberculous granu-
Iomata were present (epithelioid granuloma with caseous necrosis, giant cells and acid-fast bacilli); (c) mixed (three cases): there was a neutrophil exudate, similar to that of the exudative form, and the initial formation of the epithelioid granulomata with acid-fast bacilli. The exudative and the mixed forms were associated with a worse clinical picture and were found only in cases where the onset of TB was during the first post-transplant year. Only one patient had the granulomatous form within the first year. The remaining six cases occurred after the first post-transplant year (figure 3). Three of the six patients with the exudative or mixed forms died. No deaths occurred in patients with the granulomatous form.

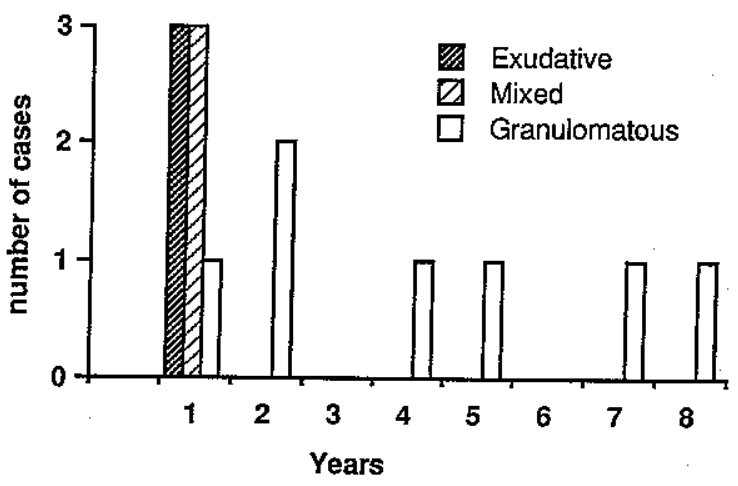

Fig. 3 - Histopathological forms and post-transplant periods.

Specific therapy consisted of different drug combinations. Isoniazid was used in all patients. The other drugs used were rifam. picin, ethambutol and streptomycin. Paraminosalicilic acid and pyrazinamide were seldom used. There was a severe rejection crisis in one patient after the start of the course of therapy, which included rifampicin. Another patient received three different drug combinations due to severe jaundice.

Of the 25 patients, 15 recovered after the rapy. There were no recurrences. The duration of the treatment ranged from 6 to 24 months. The other 10 patients died. Two deaths were unrelated to TB. Six of the eight deaths due to TB occurred during the first 6 post-transplant months. No deaths occurred in the nine patients in whom TB occurred after 3 years of transplantation.

The immunosuppression in TB patients. and in the control group was compared. The 
PAULA, F. J. de; AZEVEDO, L. S.; SALDANHA, L. B.; IANHEZ, L. E. \& SABBAGA, E. - Tuberculosis in renal transplant patients. Rev. Inst. Med. trop. São Paulo, 29:268-275, 1987.

doses of azathioprine were not statistically different. The doses of prednisone were higher although not statistically significant in TB pa. tients than in the control group. The number of rejection crises was significantly greater in TB patients (figure 4). A comparison of immunosuppressives was made also between TB patients who died and those who were cured. There were no differences in relation to azathioprine. Prednisone doses were higher and the number of rejection crises treated was greater in patients who died than in those who were cured (figure 5).

control
T8

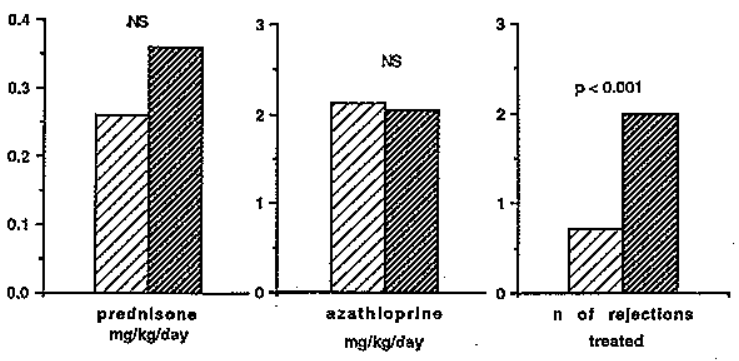

Fig. 4 - Immunosuppression in TB and in control group.

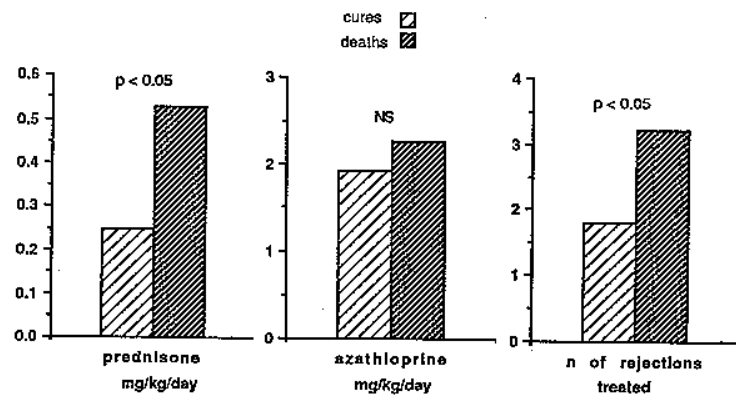

Fig. 5 - Immunosuppression in TB patients who died and who were cured.

Serum creatinine levels were not statistically different in TB patients as in the control group.

One patient developed TB in the urinary tract and in the lungs. At the same time tubercle bacilli was identified in the urine of the donor (her mother).

Two patients received isoniazid prophylactically started soon after the transplantation. This proved ineffective in preventing TB reac. tivation.

\section{DISGUSSION}

The incidence of TB in patients with chronic renal failure and renal transplants is higher than that in the general population ${ }^{2,18}$. In transplant patients it is estimated to be at 0 to $1.7 \% 8,15,16,22$. Although few studies of such cases have been published, TB in renal transplant patients is not a rare disease. LICHTENSTEIN and MacGREGOR 15 , in a survey made by questionnaires received from 26 transplant centres in the USA, reported that $14(57.7 \%)$ of them had had at least one case of TB during the last 10 years. One of the centres reported 22 cases. They estimated that the incidence of TB among transplant patients would be 313$340 / 100,000$ per year $(0.31$ to $0.34 \%)$. This is approximately 24 times greater than the incidence in the general population of the USA. In our present study (of Brazilian patients only) the incidence of TB was $5.6 \%$. This extremely high frequency of TB could be explained by the high prevalence of TB in Brazil, which is estimated to be at $0.5 \%$ of the general population ${ }^{6}$.

Immunosuppression is by far the main predisposing factor to infection in transplant. patients. Which drug is mainly responsible and the exact mechanism of this predisposition is not yet defined 20 . Azathioprine, as it is well known, impairs the host defence mechanisms against infection 20 . However, we found that there was not a significant difference between the doses of azathioprine administered to TB patients and to the control group as well as to TB patients who were cured and to those 'who died, although slightly higher in the latter. By contrast, we found that TB patients received more steroid treatment for rejection than did the control group. Oral prednisone doses were considerably higher and the num. ber of rejection crises treated were greater in TB patients who died as compared to those who were cured. TB patients received more oral prednisone than did control patients (although not statistically significant). These findings stress the role of corticosteroids as a predisposing factor in developing TB in transplant patients, as well as increasing the mortality rate in these patients. The main role of corticosteroids in predisposing infections in general, and TB in particular, is a disputed subject 5,8,16,20,29,31. Many authors propose the use of a routinely low dose of 
PAULA, F. J. de; AZEVEDO, L. S.; SALDANHA, L. B.; IANHEZ, L. E. \& SABBAGA, E. - Tuberculosis in renal transplant patients. Rev. Inst. Med. trop. São Paulo, 29:268-275, 1987.

corticosteroids to avoid side effects, the main one being infection ${ }^{20}$. LICHTENSTEIN and MacGREGOR 15 ; in their review of TB in transplant patients, found that the mean dosage of prednisone in TB patients was $34.2 \mathrm{mg}$ daily (range of 10 to $80 \mathrm{mg}$ ). This can be considered a moderate to high dose of steroids. The average dose of azathioprine was $117 \mathrm{mg}$ daily (a considerably low dose) and only four patients were receiving more than $150 \mathrm{mg}$ daily. Some authors, however, did not implicate corticosteroids as the main factor in predisposing TB infection in transplant patients $5,8,29$.

The onset of TB in the majority of our patients $(56 \%)$ occurred during the first posttransplant year, a period in which steroids are used in greater doses and when almost all rejection crises occur (table I). The dosage of azathioprine was constant throughout the years (table I). The remaining $44 \%$ of cases developed uniformly during the following 8 years. The cases which occurred early in the post-transplant period tended to be more serious and to have poorer prognosis, with a high mortality rate. The two miliary cases occurred within the first 6 post-transplant months. By contrast, the cases in which TB arose later tended to be mild and with a good prognosis. In the cases reported in the literature, there was a wide range in the time of onset of TB. LICHTENSTEIN and Mac GREGOR is stated that $64.7 \%$ of the cases occurred within the first post-transplant year. The onset ranged from 1 to 78 months.

The supposition that the well-known immunosuppressiye effect of uraemia could be present after a successful renal transplant and thus predisposing to infections ${ }^{8,31}$ is an attractive hypothesis which can not be ruled out. However, this hypothesis has not been proved and has even been rejected 10,27، Although we could suspect that patients who had had more rejection crises had a worse renal function, and thus an impaired immunity, serum creatinine leveis were not significantly different as between TB and control patients.

One point of great interest was the fact that TB appeared under three different histological pictures: exudative, granulomatous and mixed. The exudative form was present in the first months and was associated with a bad clinical picture and with a worse progno. sis. Granulomatous TB had a clinical picture similar to that found in non-immunosuppressed patients, was present mostly after the first post-transplant year and had a good prognosis. The mixed form had aspects of both forms, lying "in between". We might speculate that corticosteroids in high doses could be the main factor in inducing the appearance of the exudative and mixed forms (rather than the granulomatous one) in some of our patients du. ring the early post-transplant period.

The initial signs and symptoms of TB can be mild, undefined and polymorphic. The patient can deteriorate rapidiy if $T B$ is undiagnosed or diagnosed too late. This is more evident during the first post-transplant months. These facts are corroborated by the high mortality rate and by the fact that three of our patients had their diagnosis of TB established only at necropsy. These findings were also observed by others $5,8,19,24$. Thus the establishment of early diagnosis and immediate institution of therapy is of the utmost importance in affecting the prognosis. TB should be suspected in all ill-defined febrile conditions affecting transplant patients, and even more when lungs are affected. All attempts to establish the diagnosis should be made $16,18,26$. The presence of tubercle bacilli should be searched for on airways secretions, urine or suspected secretions, either by direct staining or by culture in specific media. As acid-fast bacilli are not frequently found and cultures may take weeks to be positive, a more aggressive approach, such as bronchoscopy or biopsy of the affected organ, is advisable. Open lung biopsy should be considered when unexplained pulmonary infiltrate is present $4,16,26$, It was performed in $\mathbf{1 0}$ of our patients, had no complications and led to positive results in all cases. In the presence of a suspected infected patient, if TB cannot quickly be confirmed, a specific "blind" therapeutic trial should be instituted. This can be life-saving.

Extra pulmonary TB occurred in 12 of our patients, some of them with multiple organ involvement. Two of them had miliary dissemination. This has been frequently cited in the literature $3,5,8,12,13,15,16,18,19,21,22,24,25,26$. The disseminated form was found to be at $43.5 \%$ of 23 cases collected by LICHTENSTEIN and MacGREGOR 15 . 
PAULA, F. J. de; AZEVEDO, L. S.; SALDANHA, L. B.; TANHEZ, L. E. \& SABBAGA, E. - Tuberculosis in renal transplant patients. Rev. Inst. Med. trop. São Paulo, 29:268-275, 1987.

Specific therapeutic regimen varies widely $3,4,8,12,15,16,18,19,21,22,24,25$ and depends on the renal function and on the presence of liver da. mage. There is no agreement on how many and which drugs should be used, and on the duration of the treatment. It is reasonable to suggest that three drugs should be used and the treatment should take one year at least. Some authors propose longer therapy, even 3 years 5,31 . The main point rests on the choice of drugs. Hepatotoxicity can be a serious side effect of TB treatment ${ }^{16,27}$. Transplant patients may have hepatopathy and azathioprine and cyclosporin can be hepatotoxic ${ }^{20}$. Thus isoniazid, rifampicin and pyrazinamide should be used with caution. One of our patients developed jaundice after the start of TB treatment; the drug combination was changed three times in order to minimise the liver damage. This approach was unsucessful and the patient eventually died of liver insufficiency.

Rifampicin poses a special problem. It can interact with microsomes of hepatocytes enhancing steroids catabolism ${ }^{11,17}$ and thus predisposing to rejection. This occurred in one of our patients. MCALLISTER et al ${ }^{17}$ found a $45 \%$ increase in the plasma clearance of prednisolone and a reduced amount of drug availability to tissues by $66 \%$ in patients receiving rifampicin. Thus oral doses of steroids should be increased during therapy with rifampicin. Rifampicin also increases the catabolism of cyclosporin, probably by activation of hepatic enzymes ${ }^{7,14}$. Increased oral doses of cyclosporin were not followed by a corresponding increase in cyclosporin blood levels, and did not prevent rejection crises in cases reported in the literature $1,9,14,23$. It has been suggested either that rifampicin should be avoided in cyclosporin-treated patients 1,23 using pyrazinamide instead 9; or that azathioprine should be used instead of cyclosporin in patients who must receive rifampicin 1 . Therefore it seems that cyclosporin and rifampicin should not be used concomitantly, but if this drug combination must be necessary, the dose of cyclosporin should be increased as much as is needed to reach therapeutic cyclosporin blood levels.

The use of isoniazid as a prophylactic agent has been proposed for patients in these con. ditions: coming from endemic TB environ. ments, with known family contacts, with sus- pected calcified lung lesions, having had previousiy inadequately treated TB or receiving a kidney from positive tuberculin tested donor $1,16,18,19,24,30$. This policy is a subject of concern. Isoniazid can induce neuropathy in patients with renal impairment and it can be hepatotoxic. Moreover, in transplant patients in whom chronic hepatopathy may be present, and who are expected to receive azathioprine and/or cyclosporin, two potentially hepatotoxio drugs 20,30 . The efficacy of isoniazid as a prophylactic agent in transplant patients has not been proved ${ }^{29}$. Two of our patients developed TB despite having received prophylactic isoniazid. This was also the case in three patients reported by SAHN and LAKSHMINARAYAN ${ }^{29}$ who received corticosteroids (one for renal transplant and two for other reasons) and prophylactic isoniazid. Although TB is highly prevalent in Brazil it is not our policy to prescribe isoniazid as a routine prophylactic drug.

TB in transplant patients is believed to be an exacerbation of previous and quiescent foci. ${ }^{31}$. However, it is possible that the serious pulmonery or disseminated TB seen during the first months of the post-transplant period could arise from prime infection. Transmission of TB from a contaminated donor via the graft has been described $13,15,21,25$. It was the case of one of our patients who developed urinary tract and pulmonary TB a few months after receiving the allograft. Urinary tract TB was diagnosed also in the donor. Retrospectively, it was found that at the time of transplantation the donor had a mild and neglected leusocyturia.

In conclusion, TB in renal transplant par tients is a serious medical complication. Its frequency is 10 to 20 times greater than that found in the general population. Morbidity and mortality are higher during the first months after the transplantation. This coincided in our series with occurrence of exudative and mixed forms. Corticosteroids in high doses are probably important factors in predisposing the patient to TB and in increasing morbidity and mortality. TB can be transmitted via the donor kidney.

\section{RESUMO}

Tuberculose em pacientes transplantados renais 
PAULA, F. J. de; AZEVEDO, L. S.; SALDANHA, L. B.; IANHEZ, L. E. \& SABBAGA, E. - Tuberculosis in renal transplant patients. Rev. Inst. Med. trop. São Paulo, 29:268-275, 1987.

Tuberculose (TB) foi diagnosticada em 25 de 466 pacientes submetidos a transplante renal. A TB surgiu entre 1 mês e 9 anos póstransplante. O pulmão foi acometido em $76 \%$ dos casos, isoladamente $(56 \%)$, ou associado a outras localizações (20\%). Os outros órgãos envolviđos foram: pele, articulações, testículos, trato urinário, sistema nervoso central e linfonodos. O diagnóstico foi confirmado por biópsia em $64 \%$ dos casos, pela identificaçăo do bacilo em $24 \%$ e apenas à necrópsia em $12 \%$. Três formas histológicas foram identificadas: exudativa (nos casos de aparecimento precoce e de maior gravidade) granulomatosa (naqueles benignos e de aparecimento tardio) e mista (naqueles intermediários). As doses de azatioprina foram constantes ao Iongo do período pós-transplante, tanto no grupo tuberculoso como no controle, bem como nos par cientes tuberculosos que faleceram e que se curaram. O número de crises de rejeição tratadas foi maior no grupo TB do que no grupo controle. As doses de pređnisona e o número de crises de rejeiçấo foram maiores nos pacientes tuberculosos que faleceram do que naqueles que sobreviveram. Quinze pacientes se curaram e 10 faleceram, oito de causas relacionadas à TB, Seis destes óbitos ocorreram nos 6 primeiros meses pós-transplante. Fm um paciente a TB foi transmitida pelo enxerto.

\section{REFERENCES}

1. AILEN, R. D. M.; HUNNISETT, A. G. \& MORRIS, P. J. - Cyclosporin and rifampicin in renal transplantation. Lancet, 1: 1342-1343, 1985.

2. ANDREW, O. T.; SCHOENFELD, P. Y.; HOPWELL, P. C. \& HUMPFREYS, M. H. - Tuberculosis in patients with end-stage renal disease. Amer. J. Med., 68: $59-65,1980$.

3. ASCHER, N. L.; SIMMONS, R. L.; MARKER, S.; KLUGMAN, J. \& NAJARIAN, J. S. - Tuberculosis joint disease in transplant patients. Amer. J. Surg., 135: 853-856, 1978.

4. Batata, M. A. - Pulmonary tuberculosis in a renal transplant recipient. J. Amer. med. Ass., 237: 1465, 1977.

5. BELL, T. J. \& WILLIAMS, G. B. - Successful treatment of tuberculosis in renal transplant recipients. J. roy. Soc. Med., 71: 265-268, 1978.

6. BRÓLIO, R. \& LIMA FHHO, M. T. - Tuberculase pulmonar. In: VERONESI, R., ed. - Doencas infeccio. sas e parasitáxias. 6." ed. Río de Janeiro, Guanabara Koogan, 1976. p. 317-338.

7. CASSIDY, M. J. D.; ZYTSSMTT, R. V.; PASCOE, M. D.; SWANEPOEL, C. R. \& JACOBSON, J. E. - Effect of rifamplcin on cyclosporin-A blood levels in a renal transplant recipients. Nephron, 41: 207, 1985.

8. COUTTS, I. I.; JEGARAJAF, S. \& STARK, J. E. Tuberculosis in renal transplant recipients. Brit J. Dis. Chest, 73: 141, 1979.

9. COWARD, R. A.; RAFTERY, A. T. \& BROWN, C. B. Cyclosporin and anti-tuberculous therapy. Lancet, I: 1342-1343, 1985.

10. DOBBELSTEIN, H. - Immune system in uremia. Nephron, 17: 409-412, 1976.

11. EDWARDS, O. M.; EVANS, R. J. C.; GALIEY, J. M; HUNTER, J. \& TAIT, A. D. - Changes in cortisol metabolism following rifampicin therapy. Lancet, 2: 549-551, 1974.

12. FORSLUND, T.; LAASONEN, L.; HECCKERSTEDT, K'; STENMAN, S. \& EDGREN, J. - Tuberculosis of the colon in a kidney transplant patient. Acta. Med. Scand., 215: 181-184, 1984.

13. LAKSHMLNARAXAN, S. \& SAHN, S. A. - Tuberculosis in a patient after renal transplantation. Tubercle, 54: 72-76, 1973.

14. I.ANGHOFF, E. \& MADSEN, S. - Rapid metabolism of cyclosporin and prednisone in kidney transplant patient receiving tuberculostatic treatment. Lancet, 2: $1031,1983$.

15. IICHTENSTEIN, T. H. \& MacGREGOR, R. R. Mycobacterial infections in renal transplant recipients: report of five cases and review of the literature. Rev. infect. Dis., 5: 216, 1983.

16. ILOVERAS, J.; PETERSON, P. K; SIMMONS, R. L. \& NAJARIAN, J. S. - Mycobacterial infections in renal transplant recipients. Arch. intem. Med., 142: 888-892, 1983.

17. MCALLISTER, W. A. C.; THOMPSON, P. J.; AL-HABET, S. M. \& ROGERS, H. J. - Rifampicin reduces effectiveness and bioavailability of prednisolene. Brit. med. J., 286: 923-925, 1983.

18. MCWHINNEY, N.; KHAN, O. \& WILLIAMS, G. Tuberculosis in patients undergolng maintenance haemodialysis and renal transplantation. Brit. J. Surg,, 68: 408-411, 1981 .

19. MILIAR, J. W. \& HORNE, N. W. - Tuberculosis: in immunosuppressed patients. Lancet, 1: 1176-1178, 1979.

20. MORRIS, P. J. ed. - Kidney transplantation. Frinciples and practice. London, Grune \& Stratton, 1984. p. 239-279. 427-467.

21. MOURAD, G.; SOULHIOU, J. D.; CHONG, G.; POVLIQUEN, M. \& HOURMANT, M. - Transmission of Mycobacterium tuberculosis with renal allografts. Nephron, 41: 82-86, 1985.

22. NEFF, T. A. \& HUDGEL, D. W. - Miliary tuberculosis in a renal transplant recipient. Amer. Rev. resp. Dis., 108: 677-678, 1973. 
PAULA, F. J. de; AZEVEDO; L. S.; SAIDANHA, L. B.; IANHEZ, L. E. \& SABBAGA, E. - zuberculosis in renal transplant patients. Rev. Inst. Med. trop. Sä० Paulo, 29:268-275, 1987.

23. OFFLRMANN, G.; KELLER, F. \& MOLZAFN, M. Low cyclosporin-A blood levels and acute graft rejection in a renal transplant recipient during rifampicin treatment. Amer. J. Nephrol., 5: 385-387, 1985.

24. ORTUNO, J.; TERUEL, J. L. \& MARCEN, R. Primary intestinal tuberculosis following renal transplantation. Nephron, 31: 59-62, 1982.

25. PETERS, T. G.; RHITER, C. G. \& BOSWELL, R. $L$. - Transmission of tuberculosis by kidney transplantation. Transplantation, 38: 514-516, 1984.

26. RATTAZZI, L. C.; SIMMONS, R. L.; SPANOS, P. K.; BRADFORD, D. S. \& NAJARIAN, J. S. - Successful management of miliary tuberculosis. Amer. J. Surg.. 130: 359-361, 1975.

27. REVILLARD, J. R. - Immunological alterations in chronic renal insuffictency. Advanc. Nephrol., 8: 365-370, 1979.
28. RIFKIND, D.; MARCHIORO, T. L.; WADDELL, W. R. \& STARZL, T. E. - Infectious diseases associated with renal homotransplantation. J. Amer. med. Ass., 189: 397-407, 1964 .

29. SAHN, S. A. \& LAKSHMMNARAYAN, S. - Tuberculosis after corticosteroid therapy. Brit. J. Dis. Chest, 70: 195-198, 1976.

30. THOMAS, P. A.; MOZES, M. F. \& JONASSON, O. Hepatic dysfunction during isoniatid chemoprophylaxis in renat allograft recipients. Arch. Surg., 114: 597-599, 1979.

31. TUBERCULOSIS in renal transplant patients. Editorial Tubercle, 60: 193-194, 1979.

Recebido para publicação em 07/2/1986. 